\title{
Working
}

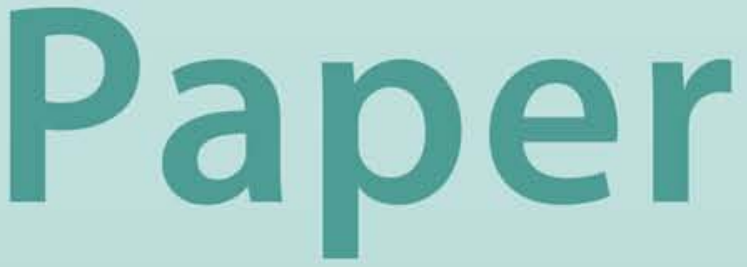


Current Account Balance Estimates for Emerging Market Economies

\author{
Leandro Medina, Jordi Prat and \\ Alun Thomas
}




\title{
IMF Working Paper
}

Western Hemisphere Department

\section{Current Account Balance Estimates for Emerging Market Economies}

\author{
Prepared by Leandro Medina, Jordi Prat, and Alun Thomas ${ }^{1}$
}

Authorized for distribution by Andreas Bauer

February 2010

\begin{abstract}
This Working Paper should not be reported as representing the views of the IMF.

The views expressed in this Working Paper are those of the author(s) and do not necessarily represent those of the IMF or IMF policy. Working Papers describe research in progress by the author(s) and are published to elicit comments and to further debate.
\end{abstract}

This paper uses a modified version of the methodology used by the IMF's Consultative Group on Exchange Rate Issues (CGER) to calculate equilibrium current account balances (or forms") for a sample of 33 emerging market economies. We find that the fundamental determinants of the equilibrium current account balances are similar to those identified by the CGER using a sample that also comprises advanced economies. However, the fiscal balance has a considerably stronger impact on current account norms for emerging markets. This paper also offers estimates for the equilibrium current account balances of eleven smaller emerging market economies that are not currently included in the country sample used by the CGER.

JEL Classification Numbers: F31, F32, F37

Keywords: Real exchange rate, macro-balance approach, current account norm Author‘s E-Mail Address: 1medina@,imf.org, jprat@imf.org, athomas@,imf.org

\footnotetext{
${ }^{1}$ We are grateful to Miguel Savastano, Martin Cerisola, Andreas Bauer, and seminar participants at the IMF for their insightful comments and guidance, and Xiomara Jordan for invaluable administrative support. Any errors are our own.
} 


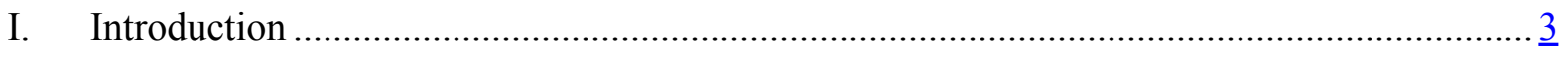

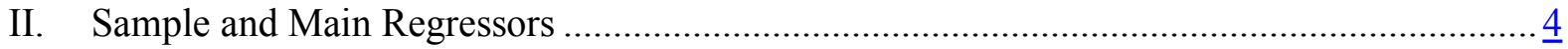

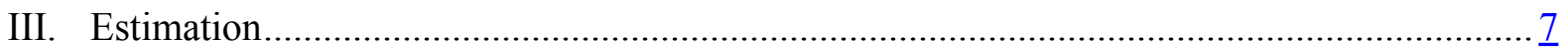

IV. Current Account Norms and Comparison with Underlying Balances .............................. 11

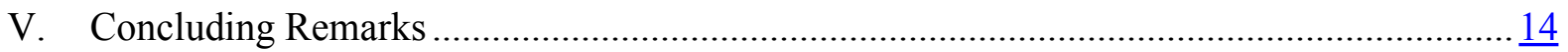

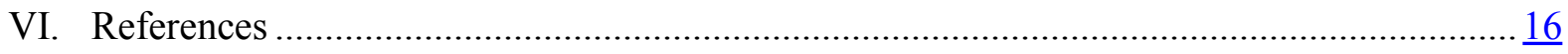

Figure

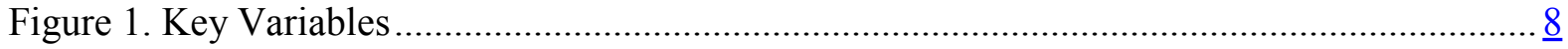

\section{Tables}

Table 1. Current Account Regression Results: Alternative Specifications ............................... 10

Table 2. Alternative Norm Estimations .......................................................................... 12

Table 3. Contribution to CA Norms ….............................................................................. 13

Table 4. Norms and Confidence Intervals-Baseline without Oil Trade Balance for Importers .... 15

\section{Appendices}

Appendix I. Sample Characteristics. ........................................................................... 19

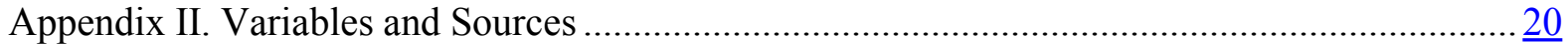

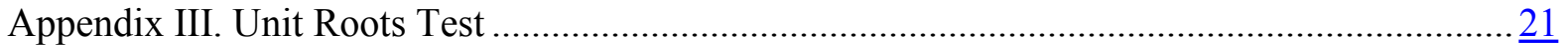

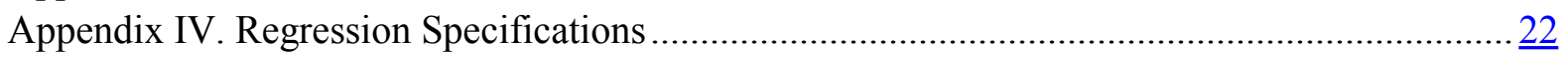




\section{INTRODUCTION}

The real exchange rate is a key relative price in the economy. It provides economic agents signals on what goods and services to produce and indicates how the structure of the economy should adjust to the external environment in the medium term. However, the real exchange rate is not directly observable, so extensive research has been undertaken to estimate it.

Methodologies to estimate equilibrium real exchange rates can be broadly classified as bivariate (examples would be the absolute and relative purchasing power parity) and multivariate (for example, the macro-balance and external sustainability approaches). ${ }^{2}$

Since 1997, the Consultative Group on Exchange Rate Issues (CGER) — an internal working group of the IMF - has been conducting biannual exchange rate assessments for a number of countries. The notion of equilibrium that underpins the CGER exercise is one of internal and external balance. Internal balance is associated with a zero output gap for the economy, while the external balance is associated with an equilibrium ' current account balance estimated as a function of economic fundamentals, and a sustainable net foreign asset or liability position. ${ }^{3}$

Existing multivariate methodologies to determine equilibrium real exchange rates can be broadly classified into three basic approaches: (i) quantity-based approaches, such as the macro-balance approach, estimate medium-term current account balances as a function of medium-term characteristics of the economy or fundamentals; (ii) price-based approaches, such as the fundamental approach, provide econometric estimates of a reduced form equation for the equilibrium real exchange rate as a function of fundamental variables like the differential in sectoral productivities, the size of the government, and terms of trade shocks; and (iii) balance sheet-based approaches, such as the external sustainability approach, determine the equilibrium current account as one consistent with a benchmark for the desired net foreign asset position.

The CGER has dedicated most of its efforts into developing the macro-balance and the external sustainability approaches, and to a lesser extent, the fundamental approach. ${ }^{4}$ For its assessments, the CGER uses a sample of 55 developed and emerging economies and provides formal estimates for 27 of them.

The basic methodology for estimating current account norms is to estimate a relationship between the current account balance and its fundamental determinants based on historical data

\footnotetext{
${ }^{2}$ For a survey of related methodologies to estimate equilibrium real exchange rates, see Williamson (1994) and Montiel (1999). Zalduendo (2008) shows that empirical estimations of the PPP are generally not robust to changes in sample and concludes that multivariate approaches generally have more predictive power and are more robust.

${ }^{3}$ For an overview of the different methodologies used by the CGER in conducting its exchange rate assessments, see Abiad, Kannan, and Lee (2009).

${ }^{4}$ See Lee, Milesi-Ferretti, Ostry, Prati, and Ricci (2008), Isard and Faruqee (1998).
} 
and then to use the coefficient estimates from this relationship with medium-term projections of the fundamental variables to provide an equilibrium current account balance (or norm") that would prevail when countries are in steady state. Implicitly, this methodology assumes that the projections of the fundamental variables themselves are in steady state. We then compare for each country the current account norm with the country's medium-term current account balance projection ( underlying').

This paper applies the macro-balance approach to a sample that consists exclusively of emerging market economies. Our contribution is twofold. First, by using only emerging markets in our sample, we abstract from the possible influence that developed economies might have on the estimation of the current account balance norms, and thus provide a robustness check for the estimates obtained by the CGER. Second, we offer for the first time estimates for eleven smaller emerging market economies that are not currently included in the country sample used by the CGER.

The paper is organized in the following way: Section II discusses the variable choice and describes the sample of countries used in the analysis and the main variables that should determine the current account norm; section III presents the regression estimates of the preferred specifications and compares them with the latest CGER estimates; section IV derives the current account norms based on the model and compares them with the underlying current account estimates; section $\mathrm{V}$ concludes.

\section{SAMPle AND MAIn REgRessors}

This study focuses on emerging economies that have placed sovereign bonds in international financial markets at least once since 1985, with sovereign risk ratings that range from single A to B3 as of June 2009. The resulting group of 33 countries yields considerable variety in terms of country characteristics (see Appendix 1). ${ }^{5}$ For instance, GDP per capita in 2008 U.S. Dollars ranges from US $\$ 1,000$ for India and Pakistan, to more than US $\$ 28,000$ for Israel. About two thirds of the countries in our sample are also part of the sample used by the CGER for its exchange rate assessments, which also includes some industrialized economies.

We estimate the determinants of current account balances using a linear reduced form model.
( 1 )

$$
\mathrm{CA}=\mathrm{X} \beta+\xi
$$

\footnotetext{
${ }^{5}$ Because of short time series, countries from Eastern Europe had to be excluded from the sample.
} 
CA is a vector of yearly current account balances in percent of GDP for every country, and X is a set of fundamental variables that includes, among others, the fiscal balance, two dependency ratios (young and old), population growth, the initial stock of foreign assets, the oil balance, GDP per capita growth, per capita income with respect to the United States, and FDI. The vector of coefficients $(\beta)$ determines the sensitivity of the current account to these fundamental variables. Finally, we include a vector of standard error terms, denoted by $\xi$ assumed to be independent and normally distributed.

We first describe the fundamental variables that we include in our specifications, including their expected relationships with the current account, and then provide the estimation results in the next section. ${ }^{6}$

- Fiscal balance. A larger fiscal deficit reduces national savings and thereby lowers the current account balance.

- Dependency ratios. Two dependency ratios are used: the young ratio (under 16) and the old ratio (over 65), both over the economically active population. A higher share of elderly tends to reduce national savings and thus decrease the current account balance as they are in the consumption stage of their life cycle. A larger share of young population should enhance future productivity growth and facilitate future repayment of current account deficits incurred in the present. Hence, we expect that both young and old dependency ratios to have a negative impact on the current account balance.

- Population growth. A country with higher population growth would have a larger future work force, which would allow it to run higher current account deficits than otherwise.

- The stock of net foreign assets (NFA). Economic agents in a country hold their wealth in assets that might be generated domestically or abroad. NFA is defined as the net holdings by domestic residents of foreign assets minus foreign liabilities. This variable enters the analysis with a one-period lag. NFA affects the current account balance in two opposite ways. First, a country with larger stock of NFA will be wealthier, which allows to finance a weaker current account balance in the medium term. Second, a country with a larger stock of NFA should also receive income as a return to holding these assets, which would imply a more positive current account balance. Given that there is no a priori reason to expect one effect

\footnotetext{
${ }^{6}$ The fundamental variables used are consistent with those used in a number of other papers on determinants of current account norms, including Lee et al. (2008), Isard and Faruqee (1998); Isard et al. (2001); Isard (2007); and Obstfeld and Rogoff (1996).
} 
to dominate over the other, the sign of the coefficient would be an empirical question.

- Oil balance. Higher oil prices increase the current account balance for oil-exporters and decrease the balance of oil-importing countries (International Monetary Fund, 2006).

- GDP per capita growth. Fast-growing economies have a higher income potential, which would allow them to have a lower level of savings today. Hence, GDP per capita growth should have a negative effect on the current account balance.

- Per capita income relative to the United States. The lower this ratio, the earlier a country's development stage, which should imply a lower (or negative) savings investment balance and current account balance. ${ }^{7}$ Hence, there should be a negative relationship between this variable and the current account.

- The ratio of foreign direct investment (FDI) to output. Current account deficits financed by FDI should be less prone to sudden stops and therefore more sustainable than those financed by other type of inflows. Hence, higher FDI should be associated with weaker current account balances (i.e. a negative coefficient).

- Asian crisis dummy. Asian countries that were most severely hit by the 1997 crisis increased their savings rates significantly after 1997 as a means of self-insuring against future external shocks (see Bautista (2007)). ${ }^{8}$ To proxy for this structural change in the behavior of their current account balances, we introduce a dummy variable that takes the value of one after 1997. The methodology used by the CGER also includes a dummy variable from 1997 onward, but it assumes that the Asian crisis effect dies out in the medium term. Hence, their savings rates would eventually revert back to pre-crisis levels.

The sample period ranges from 1970 to 2008, almost four decades of annual data (a similar period is used by the CGER for its assessments). ${ }^{9}$ The data range includes periods of economic stress and current account swings, in which many countries may have deviated significantly from their current account norms. However, we think that this variability enhances the power of our estimates. The sample includes data from the October 2009 World Economic Outlook, including on oil price projections at that moment.

\footnotetext{
${ }^{7}$ See Obstfeld and Rogoff (1996).

${ }^{8}$ Asian crisis countries in this study are the following: Indonesia, Republic of Korea, Malaysia, Philippines, and Thailand.

${ }^{9}$ See Appendix II for a description of the fundamental variables.
} 


\section{ESTIMATION}

In this section, we estimate the relationship between current account balances and their fundamental determinants. Standard econometric analysis assumes that the dependent and explanatory variables (regressors) are stationary. This assumption would allow us to use simple, pooled ordinary least squares (OLS) for the estimation. Unit root tests point to most of the variables being stationary with only a couple appearing to deviate from this assumption (see Appendix III). However, these results should be taken with a grain of salt, including because of the relatively low power of the tests or the possibility that some variables may be transitioning from one equilibrium to another. For example, the demographic variables seem to be trending during the sample period, but these variables are bounded by construction, and with a longer sample should be stationary (Figure 1). The oil balance has periods in which it diverged from the average, but in the medium term it seems to be stationary.

Our regressions include time dummies to account for the business cycle, but exclude countrylevel fixed effects (see Appendix IV). The time dummies allow us to isolate year-specific effects without having to compute five-year averages for the regressors and allow us to net out the cyclical factors in the data. ${ }^{10}$ The chosen determinants of the current account should suffice to distinguish current account balance fluctuations across countries; therefore, we do not include country fixed effects in the regressions.

Regression results are presented in Table 1, where most of the variables have the expected signs and estimations are robust to the different specifications (alternative specifications are available on request). The main results are the following:

- The coefficient of the oil balance is statistically significant in all cases and ranges between 0.2 for oil exporters and almost 0.4 for oil importers. By estimating separate oil effects for oil importers and exporters, and comparing them to the estimates obtained by the CGER, we can see that the effect on the equilibrium current account balance for oil exporters is similar. However, our estimates yield a higher effect for oil importers. That said there does not seem to be any compelling theoretical reason for oil importers to have permanently worse current account norms due to the absence of an oil endowment, so our preferred specification would be given by Column (3) in Table 1.

\footnotetext{
10 The CGER computes 5-year averages as their preferred approach.
} 
Figure 1. Key Variables 1/

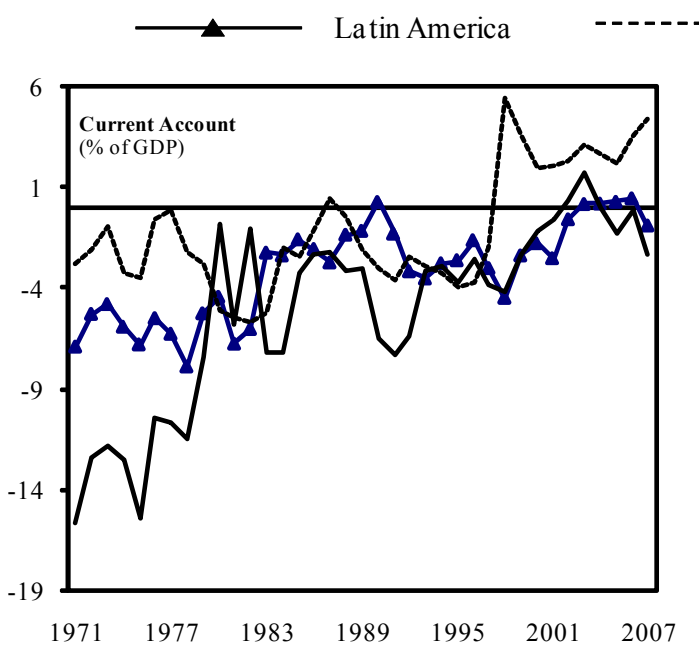

Asia

Middle East
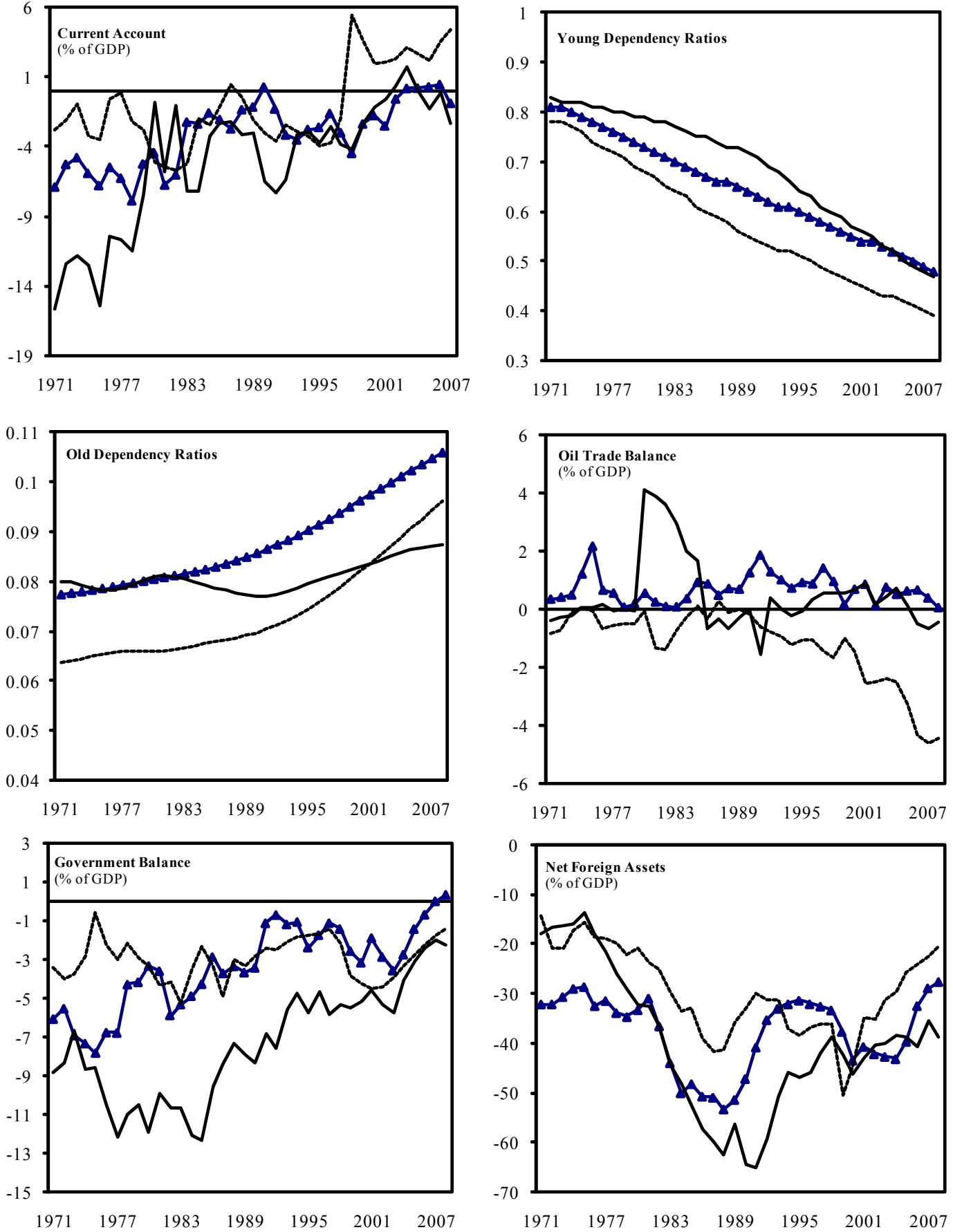

Source: Fund staff estimations.

1/ Measured as the simple average. Latin America includes Argentina, Brazil, Chile, Colombia, Costa Rica, Dominican Republic, Ecuador, El Salvador, Guatemala, Mexico, Panama, Paraguay, Peru, Uruguay and Venezuela. Asia includes China, India, Indonesia, Korea, Malaysia, Philippines, Sri Lanka, Thailand. Middle East includes Algeria, Egypt, Israel, Jordan, Lebanon, Morocco, Pakistan, South Africa, Tunisia, Turkey. 
- The coefficient for the fiscal balance is also highly significant in all specifications and fairly stable around 0.5, which is more than twice the coefficient estimated by the CGER. The stronger fiscal balance effect could reflect several factors, including that emerging economies have less developed financial markets, which implies that higher government savings are not channeled as efficiently to the private sector, and therefore would not lead to an offsetting increase in private sector demand.

- Demography matters for the current account balance. However, of the three different variables used in our regressions only the youth dependency ratio is consistently significant across all specifications, with a coefficient of around minus 0.06 in column (3), our preferred specification. This contrasts with the findings of the CGER, which uses population growth and the old-age dependency ratio and finds them statistically significant. We believe that the effects of population growth are captured indirectly by the effect of the young dependency ratio on the current account balance since the rationale for the inclusion of both variables is the same- namely a proxy for future growth.

- The stock of net foreign assets has a positive effect on current account norms. The coefficient reported in column (3) of Table 1 suggests that for every 10 percentage point of GDP increase in NFA, the current account balance improves by 0.578 percent of GDP. This effect is stronger than the one found by the CGER, which obtains a current account improvement of just 0.2 percent of GDP.

- We find that per capita output growth impacts negatively the current account. The estimated coefficient (column (3) of Table 1) is around minus 0.2, which means that higher per-capita output growth of 1 percent would lower the current account balance by 0.2 percentage points of GDP. Both the sign and direction of the estimated coefficients are consistent with those results obtained by the CGER.

- We find support for our hypothesis that Asian crisis countries experienced a structural change in their savings behavior after 1997. The Asian crisis countries group has, on average a current account norm that is more than 4 percentage points of GDP higher than other countries in the sample (see column (3) of Table 1). This result is consistent with the estimations performed by the CGER, which yield a positive effect of about 6 percent of GDP, though CGER assumes that the effect dies out over time. 
Table 1. Current Account Regression Results: Alternative Specifications

\begin{tabular}{|c|c|c|c|c|c|}
\hline & \multirow{2}{*}{ All 1/ } & \multirow{2}{*}{$\begin{array}{l}\text { All minus oil } \\
\text { exporters } 2 /\end{array}$} & \multicolumn{2}{|c|}{ Baseline } & \multirow{2}{*}{$\begin{array}{c}\text { CGER 5/ } \\
\text { (Pooled } \\
\text { Regression) }\end{array}$} \\
\hline & & & $\begin{array}{l}\text { No oil for oil } \\
\text { importers } 3 /\end{array}$ & $\begin{array}{c}\text { Oil for oil } \\
\text { importers } 4 /\end{array}$ & \\
\hline \multirow[t]{2}{*}{ Oil balance } & $0.223^{* * *}$ & $0.358^{* * *}$ & & $0.359^{* * *}$ & $0.23^{\star * *}$ \\
\hline & $(0.035)$ & $(0.075)$ & & $(0.071)$ & \\
\hline \multirow[t]{2}{*}{ FDI } & -0.159 & -0.147 & $-0.199^{*}$ & -0.148 & \\
\hline & $(0.101)$ & $(0.107)$ & $(0.102)$ & $(0.101)$ & \\
\hline \multirow[t]{2}{*}{ Fiscal balance } & $0.482^{* * *}$ & $0.526^{* * *}$ & $0.492^{* * *}$ & $0.492^{* * *}$ & $0.19^{* * *}$ \\
\hline & $(0.039)$ & $(0.044)$ & $(0.040)$ & $(0.040)$ & \\
\hline \multirow[t]{2}{*}{ Population growth } & -0.0695 & 0.235 & -0.0741 & -0.0286 & $-1.22^{\star \star}$ \\
\hline & $(0.241)$ & $(0.279)$ & $(0.244)$ & $(0.242)$ & \\
\hline \multirow[t]{2}{*}{ Young-age dependency } & $-0.0556^{\star *}$ & -0.0395 & $-0.0580^{* * *}$ & $-0.0520^{* *}$ & \\
\hline & $(0.022)$ & $(0.024)$ & $(0.022)$ & $(0.022)$ & \\
\hline \multirow[t]{2}{*}{ Old-age dependency } & -0.0404 & 0.00880 & -0.0526 & -0.0646 & $-0.14^{\star *}$ \\
\hline & $(0.107)$ & $(0.117)$ & $(0.108)$ & $(0.107)$ & \\
\hline \multirow[t]{2}{*}{ NFA } & $0.0631^{* * *}$ & $0.0595^{* * *}$ & $0.0658^{* * *}$ & $0.0630^{* * *}$ & $0.02^{* * *}$ \\
\hline & $(0.007)$ & $(0.008)$ & $(0.007)$ & $(0.007)$ & \\
\hline \multirow[t]{2}{*}{ Relative income } & -0.00554 & -0.00502 & -0.00567 & -0.00391 & $0.02^{*}$ \\
\hline & $(0.003)$ & $(0.003)$ & $(0.003)$ & $(0.003)$ & \\
\hline \multirow[t]{2}{*}{ Asian crisis } & $0.0468^{* * *}$ & $0.0457^{* * *}$ & $0.0447^{* * *}$ & $0.0468^{* * *}$ & $0.06^{\star * *}$ \\
\hline & $(0.010)$ & $(0.012)$ & $(0.011)$ & $(0.011)$ & \\
\hline \multirow[t]{2}{*}{ Output growth } & $-0.184^{* * *}$ & $-0.194^{* * *}$ & $-0.184^{* * *}$ & $-0.187^{* * *}$ & $-0.21^{\star *}$ \\
\hline & $(0.039)$ & $(0.042)$ & $(0.039)$ & $(0.032)$ & \\
\hline \multirow[t]{2}{*}{ D_Oilbalance_OilX } & & & $0.199^{\star \star \star}$ & $-0.196^{\star *}$ & \\
\hline & & & $(0.043)$ & $(0.089)$ & \\
\hline \multirow[t]{2}{*}{ Constant } & 0.0200 & -0.00737 & 0.0231 & 0.0184 & \\
\hline & $(0.030)$ & $(0.033)$ & $(0.030)$ & $(0.030)$ & \\
\hline Observations & 1044 & 921 & 1044 & 1044 & \\
\hline Number of countries & 33 & 29 & 33 & 33 & 54 \\
\hline R-squared & 0.379 & 0.352 & 0.366 & 0.382 & 0.52 \\
\hline
\end{tabular}

Standard errors in parentheses.

${ }^{* * *} p<0.01,{ }^{* *} p<0.05,{ }^{*} p<0.1$

1/ Includes all 33 countries in the sample, includes annual data 1970-2008.

2/ Excludes Oil exporters: Algeria, Ecuador, Mexico and Venezuela.

$3 /$ Excludes any permanent effect of the oil balance on the current account of oil importers.

4/ Includes differential effect of oil balance for oil importers and oil exporters.

5/ Coefficient estimates from Lee et al. (2008). 
It is important to stress that the estimates presented in Table 1 are subject to significant uncertainty and the goodness of fit is less than 40 percent, which reflects the large variation in the current account balances across countries and over time. Thus, this could be in part a result of imposing a common specification to a diverse range of countries. Furthermore, CGER has a much better fit, which may reflect the larger sample that includes developed economies, which traditionally have more stable macroeconomic histories.

\section{CURRent ACCOUnt Norms ANd Comparison with Underlying BalanCES}

We now construct estimates of the equilibrium current account balances and compare them with projected (i.e. underlying) current account balances. In line with the methodology used by the CGER, we assume that the economies in our sample will be in equilibrium 5 years into the future (i.e. 2014), the last year of the IMF's World Economic Outlook forecast. ${ }^{11}$

To compute the current account norms, we use the projected values for the relevant regressors in 2014 as inputs. The projection of the demographic variables uses growth rates from U.S. Census Bureau's international database. The time component is estimated at the mid-point of the time-varying dummies.

Table 2 shows the estimated current account norms using the baseline model. ${ }^{12}$. We find that about two thirds of the equilibrium current account balances are in deficit and vary between minus 0.1 percent of GDP for Uruguay to over minus 9 percent of GDP for Lebanon. For the rest of the sample, we obtained surplus estimates. Several of these countries are part of the Asian crisis group, which implies a very strong effect associated with the Asian crisis dummy. The equilibrium current account estimates for the surplus countries vary between 0.2 percent of GDP for Ecuador and over 17 percent of GDP for Algeria.

Compared to the current account norms estimated by the CGER, we obtain significantly different results for the Asian crisis countries, mainly due to our hypothesis that stronger current account balances reflect a permanent shift in these countries' savings behavior after the crisis. We find, on average, that Asian crisis countries have current account norms that are over 4 percent of GDP higher. For the non-Asian crisis countries in the sample for which CGER estimates are available, the results are similar to ours. ${ }^{13}$

\footnotetext{
${ }^{11}$ Projections are consistent with the published WEO data as of October 2009.

${ }^{12}$ As argued before, we find no theoretical justification for oil-importing countries to experience a negative effect on their norms as a result of the oil balance. Hence, our baseline specification will be given by the coefficients estimated in column (3) in Table 1. Discussion will center on this specification, but results for other ones are available on request.

${ }^{13}$ Except for several Asian crisis countries, all estimates of the current account norms using the CGER coefficients fall within the 90 percent confidence interval of our estimates.
} 
Table 2. Alternative Norm Estimations

\begin{tabular}{|c|c|c|}
\hline & Baseline & CGER 1/ \\
\hline Costa Rica & -2.2 & n.a. \\
\hline Dominican Republic & -4.0 & n.a. \\
\hline Ecuador & 0.2 & n.a. \\
\hline El Salvador & -2.7 & n.a. \\
\hline Guatemala & -3.4 & n.a. \\
\hline Jordan & -7.9 & n.a. \\
\hline Lebanon & -9.2 & n.a. \\
\hline Panama & -5.8 & n.a. \\
\hline Paraguay & 0.8 & n.a. \\
\hline Sri Lanka & -1.4 & n.a. \\
\hline Uruguay & -0.1 & n.a. \\
\hline Algeria & 17.2 & 14.2 \\
\hline Argentina & 1.9 & -0.6 \\
\hline Brazil & -0.5 & -0.4 \\
\hline Chile & 1.3 & -2.8 \\
\hline China & 5.6 & 2.9 \\
\hline Colombia & -0.4 & -0.4 \\
\hline Egypt & -1.2 & -1.0 \\
\hline India & -2.6 & -3.3 \\
\hline Indonesia & 5.4 & 0.0 \\
\hline Israel & 1.3 & 2.0 \\
\hline Korea & 8.3 & 0.4 \\
\hline Malaysia & 8.0 & 0.7 \\
\hline Mexico & -2.8 & -0.8 \\
\hline Morocco & -1.7 & -1.8 \\
\hline Pakistan & -2.8 & -4.3 \\
\hline Peru & -0.9 & -0.3 \\
\hline Philippines & 5.2 & -0.1 \\
\hline South Africa & -3.4 & -3.8 \\
\hline Thailand & 6.5 & -2.9 \\
\hline Tunisia & -5.4 & -0.7 \\
\hline Turkey & -4.9 & -3.4 \\
\hline Venezuela & 5.6 & 6.6 \\
\hline
\end{tabular}

1/ Estimated by using methology and coefficients from Lee et al. (2008). 
To find the drivers of the current account norms for individual countries, we decompose the effect of each fundamental variable (see Table 3 for a few examples based on the specification of column 3 in Table 2). ${ }^{14}$ Algeria has the largest current account balance norm at over 17 percent of GDP, which is mainly explained by two fundamental variables that are closely related to country's oil exports. The oil effect itself contributes about 6 percent of GDP to the current account norm and the large stock of NFA adds another 8 percent of GDP to the norm. For Malaysia, its large current account norm is mainly the result of the Asian crisis dummy (over 4 percent of GDP) and its strong NFA position, which contributes an additional 4 percent of GDP. Jordan presents a large negative population effect of almost 3 percent of GDP, a negative effect from its net foreign liability position of 6 percent of GDP, and a large negative effect from its fiscal deficit of 3 percent of GDP. In the case of Guatemala (and other Central American countries), the young population variable is relatively strong with a negative effect of about 4 percent of GDP on the norm, and the stock of NFA has a negative effect of close to 3 percent of GDP.

Table 3. Contribution to CA Norms

\begin{tabular}{lccccc} 
& Algeria & Malaysia & $\begin{array}{c}\text { Guatemala } \\
\text { (percent of GDP) }\end{array}$ & Jordan & Panama \\
\hline Norm & 17.2 & 8.0 & -3.4 & -7.9 & -5.8 \\
\hline of which & & & & & \\
$\quad$ Fiscal balance & 0.8 & -3.2 & -0.9 & -2.7 & 0.1 \\
$\quad$ Age dependency ratio (young) & -2.0 & -2.5 & -3.8 & -2.6 & -2.4 \\
$\quad$ NFA & 7.5 & 4.4 & -3.2 & -6.0 & -5.8 \\
$\quad$ Asian crisis & & 4.5 & & & \\
$\quad$ Oil trade balance * Oil producers & 6.3 & & & & \\
\hline
\end{tabular}

Source: Fund staff estimates.

To gauge deviations of the underlying current account balances from their equilibrium levels, we compute the confidence intervals for the current account norms by estimating the standard errors of the fitted value for each country. If the current account balances in the sample are normally distributed, and, under the hypothesis that the estimated norm is an unbiased estimate of the equilibrium current account, a four standard deviation confidence band will contain over 95 percent of the possible observed sample estimates. We estimate the underlying current account balances using the current account forecasts for 2014 from the IMF's October 2009 World Economic Outlook. If an underlying current account balance estimate is more than two standard deviations away from the estimated norm, the country in question may be out of equilibrium and a real exchange rate adjustment could be warranted.

\footnotetext{
14 The exercise is available upon request for all countries in the sample.
} 
The results of this exercise show that for most countries the underlying current account balances are not statistically different from their estimated norms (Table 4). The countries for which the underlying current balance is more than two standard deviations away from the norm are Algeria, Chile, Ecuador, Korea, Indonesia, Philippines, South Africa, and Thailand. Thomas et al. (2008) argue that this approach would not be appropriate for net exporters of natural resources, because it does not take into account the stock of wealth that derives from their natural resource endowment. ${ }^{15}$ Hence, our results for natural resource-rich countries like Algeria, Ecuador, and Chile should be interpreted with caution. At the same time, we find that Korea, Indonesia, Philippines, and Thailand have strong Asian crisis dummy effects. Here, our hypothesis that Asian crisis countries experienced a permanent shift in their savings behavior after 1997 is key. If the Asian crisis effects were to fade away in the medium term, the underlying current account balances for these countries would not be statistically different from their current account norms, but Malaysia would fall outside the 95 percent confidence interval. However, in order to have a more robust assessment, further analysis and use of alternative assessment methodologies would be warranted.

\section{Concluding Remarks}

This paper uses a modified version of the methodology used by the IMF's CGER to calculate current account balances that are consistent with internal and external equilibrium for a sample of 33 emerging market economies. The fundamental determinants of the equilibrium current account balances that we find are similar to those identified by the CGER using a sample that also comprises advanced economies. However, we find that the fiscal balance has a considerably stronger impact on current account norms for emerging markets. Our results also support the notion that the Asian crisis caused a permanent shift in the savings behavior of the affected countries, and that these countries tend to save more than the rest of the world (i.e. they have higher current account balance norms).

Our study offers for the first time estimates for eleven smaller emerging market economies that are not currently included in the country sample used by the CGER. Almost all of these countries have underlying current account balances that are not statistically different from their norms, which could be interpreted as evidence that these economies are pursuing policies that are consistent with external and domestic balance in the medium term. However, our estimated standard deviations are relatively large and therefore our approach should be complemented with other methods to arrive at a more rigorous assessment of the appropriateness of the policy stance in these countries.

\footnotetext{
${ }^{15}$ In addition to Thomas et al. (2008), Bems and de Carvalho (2009) provide a methodology for exchange rate assessments of natural-resource-rich economies.
} 
Table 4. Norms and Confidence Intervals Baseline - Without Oil Trade Balance for Importers

\begin{tabular}{|c|c|c|c|c|c|}
\hline \multicolumn{2}{|l|}{ Country } & Norms & SD & \multicolumn{2}{|l|}{$\begin{array}{l}2014 \\
\text { Proj. }\end{array}$} \\
\hline Colombia & & -0.4 & 1.36 & -2.1 & $1 /$ \\
\hline El Salvador & * & -2.7 & 1.37 & -2.7 & \\
\hline Brazil & & -0.5 & 1.38 & -0.8 & \\
\hline India & & -2.6 & 1.41 & -1.8 & \\
\hline Turkey & & -4.9 & 1.42 & -3.1 & \\
\hline Chile & & 1.3 & 1.44 & -2.2 & $2 /$ \\
\hline Ecuador & * & 0.2 & 1.47 & -3.2 & $2 /$ \\
\hline South Africa & & -3.4 & 1.47 & -7.5 & $2 /$ \\
\hline Costa Rica & * & -2.2 & 1.48 & -4.8 & $1 /$ \\
\hline Peru & & -0.9 & 1.50 & -1.6 & \\
\hline Morocco & & -1.7 & 1.50 & -1.0 & \\
\hline Paraguay & * & 0.8 & 1.52 & -0.8 & $1 /$ \\
\hline Pakistan & & -2.8 & 1.52 & -3.4 & \\
\hline Israel & & 1.3 & 1.52 & 2.8 & \\
\hline Sri Lanka & * & -1.4 & 1.52 & -0.7 & \\
\hline Mexico & & -2.8 & 1.53 & -1.4 & \\
\hline China & & 5.6 & 1.53 & 8.4 & $1 /$ \\
\hline Egypt & & -1.2 & 1.54 & -1.5 & \\
\hline Malaysia & & 8.0 & 1.54 & 10.8 & $1 /$ \\
\hline Dominican Republic & * & -4.0 & 1.54 & -3.4 & \\
\hline Tunisia & & -5.4 & 1.54 & -3.1 & $1 /$ \\
\hline Guatemala & * & -3.4 & 1.56 & -4.4 & \\
\hline Indonesia & & 5.4 & 1.58 & -1.0 & $3 /$ \\
\hline Korea & & 8.3 & 1.58 & 2.1 & $3 /$ \\
\hline Argentina & & 1.9 & 1.59 & 2.0 & \\
\hline Thailand & & 6.5 & 1.60 & 1.6 & 2/ \\
\hline Philippines & & 5.2 & 1.63 & 0.9 & $2 /$ \\
\hline Panama & * & -5.8 & 1.61 & -6.0 & \\
\hline Venezuela & & 5.6 & 1.66 & 5.7 & \\
\hline Jordan & * & -7.9 & 1.67 & -7.0 & \\
\hline Algeria & & 17.2 & 1.82 & 8.2 & $3 /$ \\
\hline Lebanon & * & -9.2 & 2.00 & -9.3 & \\
\hline Uruguay & * & -0.1 & 2.87 & -0.1 & \\
\hline
\end{tabular}

* Not included in CGER sample.

$1 /$ Included in the 95 percent confidence interval.

$2 /$ Included in the 99 percent confidence interval.

3 / Statistically different from norm at 99 confidence level. 


\section{REFERENCES}

Abiad, A., P. Kannan, and J. Lee, 2009, Evaluating Historical CGER Assessments: How Well Have They Predicted Subsequent Exchange Rate Movements?," IMF Working Paper 09/32 (Washington, DC: International Monetary Fund).

Bautista, C., 2007, Savings and Investment Relationship, Financial Crisis, and Strucutural Changes in East Asia Countries," Economie Internationale, Vol 111, December, pp. 1240-1323.

Bayoumi, T, Hamid Faruqee, and J. Lee, 2005, A Fair Exchange? Theory and Practice of Calculating Equilibrium Exchange Rates," IMF Working Paper 05/229 (Washington, DC: International Monetary Fund).

Bems, R. and I. de Carvalho Filho, 2009, Exchange Rate Assessments: Methodologies fro Oil Exporting Countries," IMF Working Paper 09/xx (Washington, DC: International Monetary Fund).

Chinn, M., and W. Prasad, 2003, Medium-Term Determinants of Current Accounts in Industrial Countries: An Empirical Exploration," Journal of International Economics, Vol. 59, No. 1, pp. 47-76.

Choudhri, E. and M. Khan, 2005, Real Exchange Rates in Developing Countries: Are Balassa-Samuelson Effects Present?” IMF Staff Papers, Vol. 52 (December), pp. 387-409.

Faruqee, H., 1995, Eong-Run Determinants of the Real Exchange Rate: A Stock-Flow Perspective," IMF Staff Papers, Vol. 42 (March), pp. 80-107.

Felipe, J., K. Kintanar and J. Anthony Lim, 2006, Asia's Current Account Surplus: Savings Glut or Investment Drought?” Asian Development Review, Vol. 23 (1).

International Monetary Fund, 2004, Algeria: Financial System Stability Assessment, including Reports on the Observance of Standards and Codes on the following topics: Monetary and Financial Policy Transparency and Banking Supervision, Washington, DC.

International Monetary Fund, 2005, Global Imbalances: A Saving and Investment Perspective, World Economic Outloook, Washington, DC. 
International Monetary Fund, 2006, Globalization and Inflation, World Economic Outloook, Washington, DC.

Isard, P. and H. Faruqee, 1998, Exchange Rate Assessment: Extension of the Macroeconomic Balance Approach, IMF Paper No. 167, (Washington, DC: International Monetary Fund).

Isard, P., 2007, Equilibrium Echange Rates: Assessment Methodologies,” IMF Working Paper 07/296 (Washington, DC: International Monetary Fund).

Isard, P., R. Kinkaid, and M. Fetherston, 2001, Methodology for Current Account and Exchange Rate Assessment, IMF Occassional Paper No. 209 (Washington, DC: IMF).

Lane, P. and G.M. Milesi-Ferretti, 2001, tong-Term Capital Movements," in NBER Macroeconomics Annual 2001 (Cambridge, MA: National Bureau of Economic Research).

Lane, P. and G.M. Milesi-Ferretti, 2004, - Tb Transfer Problem Revisited: Net Foreign Assets and Real Exchange Rates," Review of Economics and Statistics, Vol. 86 (November), pp. 841-57.

Lee, J., G.M. Milesi-Ferretti, J. Ostry, A. Prati, and L.A. Ricci, 2008, Exchange Rate Assessments: CGER Methodologies, IMF Occasional Paper No. 261, (Washington, DC: International Monetary Fund).

MacDonald, Ronald, and L.A. Ricci, 2003, -Estiration of the Equilibrium Real Exchange Rate for South Africa," IMF Working Paper 03/44 (Washington, DC: International Monetary Fund).

MacDonald, R. and L.A. Ricci, 2005, - ThReal Exchange Rate and the Balassa-Samuelson Effect: The Role fo the Distribution Sector," Pacific Economic Review, Vol. 10, No. 1, pp. 29-48.

Moody's Invetors Service, 2003, Moody's Rating Symbols \& Definitions," Moody‘s Assurance Company, Inc.

Nasution, A., 2007, Global Savings-Investment Imbalances: What Role for East Asia?" Asian Economic Papers, Spring/Summer, Vol. 6, No. 2, pp. 1-13.

Rahman, J., 2008, Eurrent Account Developments in New Member States of the European Union: Equilibrium, Excess and EU-Phoria," IMF Working Paper 08/92 (Washington). 
Ricci, L., G. M. Milesi-Ferretti, and J. Lee, 2008, Real Exchange Rates and Fundamentals: A Cross-Country Perspective," IMF Working Paper 08/13 (Washington, DC: International Monetary Fund).

Smyth, R., 2007, Asia“s Booming Economies a Decade After the Crisis," Economic Papers, Septmeber, Vol. 26, No. 3, pp. 193-195.

Thomas, A., J. Il Kim and A. Aslam, Equilibrium Non-Oil Current Account Assessment for Oil Producing Countries,” IMF Working Paper 08/13 (Washington, DC: International Monetary Fund).

Williamson, J. (Editor), 1994, Estimating Equilibrium Exchange Rates. Washington: Institute for International Economics.

Zalduendo, J., 2008, Bivariate Assessments of Real Exchange Rates Using PPP Data," IMF Working Paper 08/153 (Washington, DC: International Monetary Fund). 


\section{Appendix I-Sample Characteristics}

\begin{tabular}{|c|c|c|c|c|c|}
\hline \multirow[t]{3}{*}{ Country } & \multirow{3}{*}{$\begin{array}{l}\text { GDP per cap } \\
\text { (US\$ in 2008) }\end{array}$} & \multicolumn{4}{|c|}{$\begin{array}{l}\text { Government Bond Ratings } 1 / \\
\text { (Ratings displayed are as of July } 28,2009\end{array}$} \\
\hline & & \multicolumn{2}{|c|}{ Foreign Currency } & \multicolumn{2}{|c|}{ Local Currency } \\
\hline & & Rating & Outlook & Rating & Outlook \\
\hline Algeria 2/ & $4,588.2$ & n.a & n.a & n.a & n.a \\
\hline Argentina & $8,214.1$ & B3 & STA & B3 & STA \\
\hline Brazil & $8,197.4$ & $\mathrm{Ba} 1$ & STA & Ba1 & STA \\
\hline Chile & $10,123.8$ & $\mathrm{~A} 1$ & POS & A1 & POS \\
\hline China & $3,315.3$ & $\mathrm{~A} 1$ & STA & A1 & STA \\
\hline Colombia & $4,985.2$ & Ba1 & STA & Baa3 & STA \\
\hline Costa Rica & $6,579.9$ & Ba1 & POS & $\mathrm{Ba1}$ & POS \\
\hline Dominican Republic & $5,122.0$ & B2 & STA & B2 & STA \\
\hline Ecuador & $3,776.3$ & $\mathrm{Ca}$ & NEG & B3 & STA \\
\hline Egypt & $2,160.9$ & $\mathrm{Ba} 1$ & NEG & $\mathrm{Ba} 1$ & NEG \\
\hline El Salvador & $3,823.6$ & Baa3 & STA & Baa2 & STA \\
\hline Guatemala & $2,848.1$ & $\mathrm{Ba} 2$ & STA & Ba1 & STA \\
\hline India & $1,016.2$ & Baa3 & STA & $\mathrm{Ba} 2$ & STA \\
\hline Indonesia & $2,246.3$ & Ba3 & POS & Ba3 & POS \\
\hline Israel & $28,365.4$ & $\mathrm{~A} 1$ & STA & A1 & STA \\
\hline Jordan & $3,421.4$ & $\mathrm{Ba} 2$ & STA & Baa3 & STA \\
\hline Korea & $19,504.5$ & $\mathrm{~A} 2$ & STA & A2 & STA \\
\hline Lebanon & 7,616.6 & B2 & STA & B2 & STA \\
\hline Malaysia & $8,140.7$ & A3 & STA & A3 & STA \\
\hline Mexico & $10,234.8$ & Baa1 & STA & Baa1 & STA \\
\hline Morocco & $2,748.2$ & Ba1 & STA & Ba1 & STA \\
\hline Pakistan & $1,044.5$ & B3 & NEG & B3 & NEG \\
\hline Panama & $6,784.1$ & $\mathrm{Ba} 1$ & STA & n.a & n.a \\
\hline Paraguay & $2,601.1$ & B3 & STA & B3 & STA \\
\hline Peru & $4,452.5$ & Ba1 & STA & Baa3 & STA \\
\hline Philippines & $1,866.0$ & Ba3 & STA & Ba3 & STA \\
\hline South Africa & $5,693.3$ & A3 & STA & A3 & STA \\
\hline Sri Lanka 2/ & $1,971.8$ & Baa1 & NEG & Baa1 & NEG \\
\hline Thailand & $4,115.3$ & Baa1 & NEG & Baa1 & NEG \\
\hline Tunisia & 3,907.2 & Baa2 & STA & Baa2 & STA \\
\hline Turkey & $10,471.7$ & Ba3 & STA & Ba3 & STA \\
\hline Uruguay & $10,081.9$ & $\mathrm{Ba} 3$ & STA & $\mathrm{Ba3}$ & STA \\
\hline Venezuela & $11,388.3$ & B2 & STA & B1 & STA \\
\hline
\end{tabular}

Sources: Bloomberg and IMF.

1/ Rating from Moody's Investor Service.

2/ Even though Algeria does not have an official sovereign rating by any major rating agency, the Algeria's 2004 FSSA examined the costs of issuing sovereign debt. The yield of this simulated bond would be consistent with other emerging markets with 'close to investment grade' level. Since 2004, Algeria has increased its net international reserves and has retired its entire stock of debt, which would likely improve its sovereign rating if it had any debt outstanding in the market. 3/ Rating for Moody's not available, equivalent rating using S\&P. 


\section{Appendix II-Variables and Sources}

The data sample includes 33 countries, with annual data for the period 1970 to 2008 . The main data sources are the World Economic Outlook (WEO), The World Bank's World Development Indicators (WDI), and the U.S. Census Bureau's International Data Base (IDB).

Definitions of each variable are as follows:

Current Account Balance (dependent variable): Calculated as the ratio of the Current Account Balance (BCA) to nominal GDP in current U.S. dollars. Source: WEO.

Oil Balance: Calculated as the ratio of the Oil Trade Balance (TBO) to nominal GDP in current U.S. dollars. Source: WEO.

FDI: Calculated as the ratio of Direct Investment (BFD) to nominal GDP in current U.S. dollars.. Source: WEO.

Fiscal Balance: Calculated as the ratio of the General Government Balance (GGB) to nominal GDP in current U.S. dollars. Source: WEO.

Population Growth: Calculated as growth rate in Total Population (LP). Source: WEO.

Young-Age Dependency: Calculated as the ratio of the population between 0 and 14 years of age and the population between 15 and 64 years of age. Sources: The World Bank and the U.S. Census Bureau's International Data Base (IDB).

Old-Age Dependency: Calculated as the ratio of the population of 65 years and more of age and the population between 15 and 64 years of age. Sources: The World Bank and U.S. Census Bureau's International Data Base (IDB).

NFA: Calculated as the ratio of the Net Foreign Assets to nominal GDP in current U.S. dollars. Source: Lane and Milessi-Ferreti (2004) and updates from the IMF Research Department.

Relative Income: Measured as the logarithm of the initial US GDP per capita minus the initial GDP per capita of the country in U. S. Dollars. Source: WEO.

Asian Crisis: A dummy variable equal to one for the period of 1997-2008, applied to the following countries: Indonesia, Korea, Malaysia, Philippines and Thailand.

Output Growth: Measured as the growth rate of the GDP at constant prices. Source: WEO. 


\section{Appendix III-Unit Roots Test}

\begin{tabular}{|c|c|c|c|c|c|c|c|}
\hline & Levin-Lin-Chu & Harris-Tzavalis & Breitung & Im-Pesaran-Shin & $\begin{array}{c}\text { Fisher-type } \\
\text { (Based on Dfuller } \\
\text { tests) }\end{array}$ & $\begin{array}{c}\text { Fisher-type } \\
\text { (Based on } \\
\text { Pperron tests) } \\
\end{array}$ & Hadri \\
\hline Current account & 0.0000 & 0.0000 & 0.0000 & 0.0000 & 0.0003 & 0.0000 & 0.0000 \\
\hline Oil balance & 0.8000 & 0.0000 & 0.3000 & 0.0000 & 0.1550 & 0.7900 & 0.0000 \\
\hline FDI & 0.0000 & 0.0000 & 0.0000 & 0.8800 & 0.0000 & 0.0000 & 0.0000 \\
\hline Fiscal balance $1 /$ & na & na & na & 0.0000 & 0.0000 & 0.0000 & na \\
\hline Population growth & 0.0003 & 0.0000 & 0.0044 & 0.0000 & 0.5600 & 0.0000 & 0.0000 \\
\hline Young-age dependency & 0.0000 & 1.0000 & 1.0000 & 1.0000 & 1.0000 & 0.0000 & 0.0000 \\
\hline Old-age dependency & 1.0000 & 1.0000 & 1.0000 & 1.0000 & 0.9934 & 0.0461 & 0.0000 \\
\hline NFA & 0.1657 & 0.0000 & 0.0014 & 0.6900 & 0.0182 & 0.3200 & 0.0000 \\
\hline Output growth & 0.0000 & 0.0000 & 0.0000 & 0.0000 & 0.0000 & 0.0000 & 0.0000 \\
\hline
\end{tabular}

1/ The test requires a strongly balanced panel. 


\section{Appendix IV-Regression Specifications}

The first column in Table 1 includes all variables, and does not differentiate between oil exporters and importers. Most of the coefficients have the expected signs and several are statistically significant.

The second regression column excludes oil exporters (Venezuela, Algeria, Ecuador, and Mexico) and shows that the coefficient estimates remain fairly stable.

The third regression, which is our preferred specification, includes a dummy variable for oil exporters The argument for treating oil exporting countries differently (with respect to oilimporters) is that their current account norms are highly dependent on the speed of oil extraction and their stock of oil reserves.

The regression in the fourth column includes a differential oil balance effect for oil importers and oil exporters although we remain skeptical of the theoretical validity that countries with large oil-related deficits should be able to sustain larger current account deficits in equilibrium, since this implies that oil exporters would be willing to permanently lend to these economies in equilibrium.

The last column presents the coefficient estimates from Lee et al. (2008). 